\title{
Formulation and Evaluation of Chronotherapeutic Pulsatile Drug Delivery System Containing Rabeprazole Sodium
}

\author{
Ashish Kumar Garg ${ }^{1}$, Aakrshan Kumar ${ }^{1}$, Sunita Rani ${ }^{2}$, Mandeep $\operatorname{Singh}^{3}$, Amit Sharma ${ }^{3}$, Rajesh Kumar ${ }^{3^{*}}$ \\ ${ }^{1}$ Akal College of Pharmacy and Technical Education, Mastuana Sahib, Sangrur, Punjab, India. \\ ${ }^{2}$ Adesh Institute of Pharmacy and Biomedical Sciences, Adesh University, Bathinda, Punjab, India . \\ ${ }^{3}$ Rayat-Bahra Institute of Pharmacy, V. Bohan, Hoshiarpur, Punjab, India.
}

\begin{tabular}{|c|c|}
\hline ARTICLE INFO & ABSTRACT \\
\hline Article history: & \multirow{10}{*}{$\begin{array}{l}\text { Pulsatile Drug Delivery systems (PDDS) are basically time-controlled drug delivery systems in which the } \\
\text { system controls the lag time and drug is released in an immediate or extended fashion. The present study was } \\
\text { conducted to develop and evaluate pulsatile release tablets of Rabeprazole sodium for the treatment of peptic } \\
\text { ulcers. The compression coated tablets consisted of a core tablet containing drug with superdisintegrant, which } \\
\text { was further coated by erodible outer layer consisted of HPMC K4M, ethyl cellulose and xanthan gum. After } \\
\text { carrying out preformulation studies, the developed tablets were evaluated for post-compression parameters like } \\
\text { weight variation, thickness, hardness, friability, drug content and in-vitro drug release study. The best } \\
\text { formulation was selected on the basis of post-compression parameters and was subjected to accelerated stability } \\
\text { studies for } 1 \text { month. Amongst } 6 \text { formulations prepared, C5 produced convincing results with a maximum } \\
\text { cumulative drug release of } 99.97 \% \text { in } 195 \text { minutes. Also the formulation didn't show any significant changes } \\
\text { during } 1 \text { month period of stress testing. By virtue of its release pattern and delivering the drug at the right time, } \\
\text { right place and in right amounts, the developed delivery system holds good promises of benefiting the patients } \\
\text { suffering from peptic ulcers. }\end{array}$} \\
\hline Received on: 28/10/2016 & \\
\hline Accepted on: 04/12/2016 & \\
\hline Available online: $27 / 02 / 2017$ & \\
\hline Key words: & \\
\hline Pulsatile, Chronotherapeutic, & \\
\hline Circadian rhythms, Proton & \\
\hline & \\
\hline Superdisintegrant. & \\
\hline & \\
\hline
\end{tabular}

\section{INTRODUCTION}

Oral controlled drug delivery systems represent the most popular form of controlled drug delivery systems for the obvious advantages of oral route of drug administration. Such systems release the drug with constant or variable release rates as per the need. These dosage forms offer many advantages, such as nearly constant drug level at the site of action, prevention of peak-valley fluctuations, reduction in dose of drug, reduced dosage frequency, avoidance of side effects, and improved patient compliance, however, there are certain conditions for which such a release pattern is not desirable. These conditions demand release of drug after a lag time. In other words, it is required that the drug should not be released during the initial

\footnotetext{
* Corresponding Author

Rajesh Kumar, Rayat-Bahra Institute of Pharmacy, V. Bohan,

Hoshiarpur, Punjab, India.E-mail: rajksach09@gmail.com
}

phase of dosage form administration. Such a release pattern is known as time controlled or pulsatile release (Kadam and Gattani, 2010; Solanki et al., 2016).

Pulsatile drug delivery system is defined as the rapid and transient release of certain amount of drug molecules within a short time period immediately after a predetermined off-release period, i.e. lag time. This delivery system aims to release the drug on programmed pattern i.e. at appropriate time and at appropriate site of action (Singh et al., 2016).

A single dosage form provides an initial dose of drug followed by one release-free interval, after which second dose of drug is released, which is followed by additional release-free interval and then pulse of drug release. The pulsatile effect, i.e. the release of drug as a "pulse" after a lag time has to be designed in such a way that a complete and rapid drug release should follow the lag time. Pulsatile systems are designed in a manner that the drug is available at the site of action at the right time in the right amount (Ramakrishna and Rani, 2016). 
In recent years, there is a continuous interest in the development of controlled drug release systems to achieve the optimal therapeutic effect of drugs. This is based on the increasing awareness of the importance of circadian rhythms with respect to physiology, disease state and drug action which has given rise to the related fields of chronotherapeutics and chronopharmacology. The principle rationale for the use of pulsatile release is for the drugs where a constant drug release, i.e., a zero-order release is not desired (Arora et al., 2006).

The pulsatile/delayed release process may be started in response to external signals or alternatively, be regulated by inherent mechanisms, as in the case of time-controlled devices that are expected to perform consistently irrespective of major physiological variables. Coatings with differing compositions are applied to solid cores that contain the active ingredient in order to defer the onset of its release as they help in the development of desired results (Singh and Koland, 2016). Indeed, the assessment of temporal rhythms in an increasing number of disease states, the consolidation of chronotherapeutic approaches and a growing awareness of the impact of patient compliance are likely to strengthen the research efforts towards the design, preparation and evaluation of such devices (Gandhi et al., 2014; Kadam et al., 2016).

Normal gastric acid secretion follows a circadian rhythm. Immediately after meals, intragastric $\mathrm{pH}$ is elevated by the buffering effect of food but since meals also stimulate acid secretion, which results in decrease in intra-gastric $\mathrm{pH}$ later on. Gastric acid secretion is most pronounced in the evening and early night that results in a surge of gastric acidity at around $2 \mathrm{am}$, which starts decreasing later on (van Herwaarden et al., 1999).

In patients suffering from gastroesophageal reflux disease (GERD), prolonged nocturnal esophageal acid exposure has been shown to contribute to the development of erosive esophagitis (Hatlebakk et al., 1997). During night, reflux episodes are of longer duration owing to loss of gravity mediated drainage and decrease in swallows that result in reduction of primary peristalsis and thus delivery of saliva to the distal esophagus during sleep. As a result of this, the reported night-time reflux symptoms include heartburn, a bitter or sour taste in mouth, burning sensation in throat, coughing and morning phlegm. These symptoms adversely affect the sleep as well as impair functional abilities during daytime (Shaker et al., 2003).

The model drug selected for the present work is Rabeprazole sodium (Anti-ulcer agent; Proton Pump Inhibitors). Its chemical name is 2-\{[4-(3-methoxypropoxy)-3-methylpyridine2-yl]methanesulfinyl $\}-1 \mathrm{H}-1,3$-benzodiazole with a molecular formula $\mathrm{C}_{18} \mathrm{H}_{21} \mathrm{~N}_{3} \mathrm{O}_{3} \mathrm{~S}$ and molecular weight $359.444 \mathrm{~g} / \mathrm{mol}$. Rabeprazole sodium (RS) is white to off-white crystalline powder which is freely soluble in water, soluble in chloroform, methanol and ethyl acetate (I.P., 2007). The drug acts by suppressing the final step in gastric acid production by covalently binding to the $(\mathrm{H}+, \mathrm{K}+)$-ATPase enzyme system at the secretory surface of the gastric parietal cell. The binding to the $(\mathrm{H}+, \mathrm{K}+)$-ATPase results in a duration of antisecretory effect. PPIs are indicated in the management of acid-related disorders such as GERD and peptic ulcer disease, in association with Helicobacter pylori eradication therapy when needed (Fabio et al., 2007).

Rabeprazole sodium has not been formulated into pulsatile released drug delivery system. The proposed formulation comprises of a core tablet, containing Rabeprazole sodium and superdisintegrant with an erodible outer coating layer of polymer so that an immediate pulse of drug release can be achieved. Further, the compression coating of core tablet was done by using cellulosic polymers so as to have a lag time where there is no drug release. Thus, the proposed delivery system by achieving a rapid drug release (sigmoidal drug release curve) immediately after lag time, attempts to overcome the challenge of prompt drug release (Parmar et al., 2009). Moreover, the formulation attempts to alleviate the challenge associated with delivery of acid-labile nature of Rabeprazole sodium (Tirpude and Puranik, 2011).

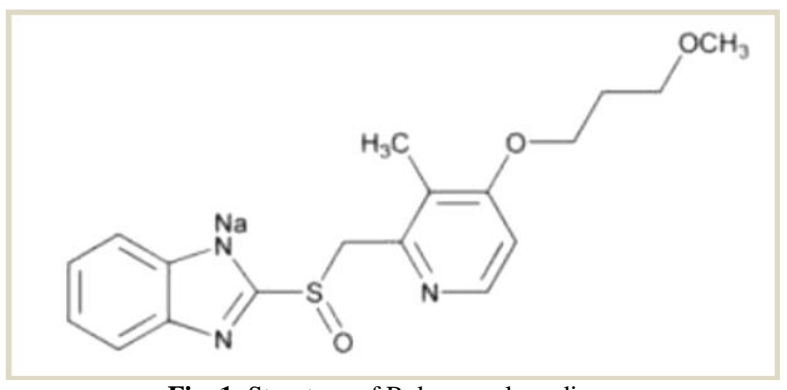

Fig. 1. Structure of Rabeprazole sodium

\section{MATERIALS AND METHODS}

\section{Materials}

Rabeprazole was obtained as an ex-gratis sample from Magbro Healthcare Ltd., H.P., India. Ethyl cellulose (Sigma Aldrich Ltd. Mumbai); Xanthan gum, HPMC K100M, Microcrystalline cellulose \& Croscarmellose sodium (CCS) from Yarrow Chem. Ltd., Mumbai, were purchased. All other reagents used in the study were of analytical grade and were used as received.

\section{Preformulation Studies Melting Point}

Melting point of the drugs was determined by taking a small amount of drug in a capillary tube closed at one end and was placed in Theil's melting point apparatus and the temperature at which the drug melted was noted down (Jona et al., 1995).

\section{Assay}

Assay of the drug was performed by UV spectrophotometric method. Rabeprazole sodium $(10 \mathrm{mg})$ was dissolved in few $\mathrm{ml}$ of phosphate buffer $(\mathrm{pH}$ 6.8) and volume was made up to $100 \mathrm{ml}$ in volumetric flask using phosphate buffer $(\mathrm{pH}$ 6.8). From this stock solution $1 \mathrm{ml}$ solution was withdrawn and diluted up to $10 \mathrm{ml}$ in volumetric flask $(10 \mu \mathrm{g} / \mathrm{ml})$. The absorbance of the solution was measured at $284 \mathrm{~nm}$ using UV spectrophotometer. 


\section{Partition Coefficient}

The partition coefficient of the drug was determined by taking equal volumes of n-octanol and aqueous phases in a separating funnel. A drug solution was prepared and $1 \mathrm{ml}$ of the solution was added to n-octanol: water (50:50) taken in a separating funnel, shaken for 10 minutes and allowed to stand for $1 \mathrm{~h}$, it was continued for $24 \mathrm{hrs}$. Then aqueous phase and octanol phase were separated, centrifuged for $10 \mathrm{~min}$ at $2000 \mathrm{rpm}$. The aqueous phase and octanol phase were assayed before and after partitioning using UV Spectrophotometer at their respective $\lambda_{\max }$ (i.e. $284 \& 280 \mathrm{~nm}$ ) to get partition coefficient (Jona et al., 1995).

\section{pH Stability profile}

The $\mathrm{pH}$ stability profile of $\mathrm{RS}$ was studied at $37^{\circ} \mathrm{C}$ and the percentage of original drug left after 24 hours of elapsed time was determined. Stock solution $(1 \mathrm{mg} / \mathrm{ml})$ of drug was prepared in different standard pH (1 to 8) solution. After 24 hours, percentage concentration of RS was determined by UV spectrophotometric method at $284 \mathrm{~nm}$. A graph between $\mathrm{pH}$ vs \% drug remaining after 24 hours was plotted.

\section{Calibration curve for Rabeprazole sodium in $0.1 \mathrm{~N} \mathrm{HCl}$}

$10 \mathrm{mg}$ of accurately weighed drug was dissolved in $0.1 \mathrm{~N}$ $\mathrm{HCl}$ in a $100 \mathrm{ml}$ volumetric flask and volume was made up with $0.1 \mathrm{~N} \mathrm{HCl}$ to get a concentration of $100 \mu \mathrm{g} / \mathrm{ml}$.

From the above stock solution, various dilutions were prepared to get the concentrations in a range of $5 \mu \mathrm{g}-30 \mu \mathrm{g} / \mathrm{ml}$. The working standard was scanned for $\lambda_{\max }$ using UV visible spectrophotometer.

\section{Calibration curve for Rabeprazole sodium in pH 6.8 Phosphate Buffer}

Following the above procedure, $10 \mathrm{mg}$ of accurately weighed drug was dissolved in $\mathrm{pH} 6.8$ phosphate buffer in a 100 $\mathrm{ml}$ volumetric flask and volume was made up using the same buffer to get a concentration of $100 \mu \mathrm{g} / \mathrm{ml}$.

From the above stock solution, various dilutions were prepared to get the concentrations in a range of $5 \mu \mathrm{g}-30 \mu \mathrm{g} / \mathrm{ml}$. The working standard was scanned for $\lambda_{\max }$ using UV visible spectrophotometer.

\section{FTIR Analysis}

FTIR analysis was carried out to find out the compatibility between the drug and excipients such as hydroxyl propyl methyl cellulose (HPMC K100 M), Xanthan gum, Magnesium stearate, Ethyl cellulose (EC), Microcrystalline cellulose (MC). Samples were prepared for drug, polymer and physical mixture of drug and polymer. The spectra obtained were compared and interpreted for the functional group bands.

\section{Formulation of Rabeprazole Sodium Pulsatile Release Tablets}

The pulsatile tablets prepared by compression coating method consisted of two different parts: a core tablet, containing the active ingredient and an erodible outer coating layer of polymer as shown in table 1 . The rapid release core tablets were prepared by using superdisintegrant along with active ingredient. Compression coating of optimized core tablets was done by using HPMC K100M and EC along with xanthan gum as a binder for strengthening of coating layer. The effect of formulation composition on the barrier layer comprising both polymers, excipients on the lag time of drug release was investigated. The compression coated tablets were evaluated for weight variation test, thickness, hardness, friability, lag time and dissolution study. Each tablet contained $20 \mathrm{mg}$ of RS (Duppada et al., 2014; Maroni et al., 2010).

Table 1: Formulation ingredients.

\begin{tabular}{lcccccc}
\hline Formulations & C1 & C2 & C3 & C4 & C5 & C6 \\
\hline Ingredients (mg) & Core tablet formulation & & & \\
\hline Rabeprazole & 20 & 20 & 20 & 20 & 20 & 20 \\
CCS & 3 & 3 & 3 & 3 & 3 & 3 \\
MCC (PH-102) & 44 & 44 & 44 & 44 & 44 & 44 \\
Magnesium stearate & 1.5 & 1.5 & 1.5 & 1.5 & 1.5 & 1.5 \\
Talc & 1.5 & 1.5 & 1.5 & 1.5 & 1.5 & 1.5 \\
\hline Coating layer formulation & & & & & \\
\hline HPMC K100M & 55 & 65 & 75 & 85 & 100 & 105 \\
EC & 70 & 60 & 50 & 40 & 25 & 20 \\
Talc & 0.5 & 0.5 & 0.5 & 0.5 & 0.5 & 0.5 \\
Magnesium stearate & 0.5 & 0.5 & 0.5 & 0.5 & 0.5 & 0.5 \\
Xanthan Gum & 4 & 4 & 4 & 4 & 4 & 4 \\
\hline
\end{tabular}

\section{Evaluation}

\section{Pre-compression characterization}

It included recording of colour and odour of the drug using descriptive terminology. Record of colour of early batches is very useful in establishing appropriate specifications for later production (Carter SJ, 1986; Sinko and Singh, 2011).

Density

Powder density may influence compressibility, sphericity, pellet porosity, dissolution and other properties.

Bulk density $(B D)$

Bulk density is ratio of mass of powder to bulk volume of powder. The parameter was measured following standard procedure. The equation for determining bulk density is

$$
\rho_{b}=\mathrm{m} / \mathrm{v}_{\mathrm{b}} \text {---------- }(1)
$$

Where,

$\rho_{\mathrm{b}}=$ Bulk density

$\mathrm{m}=$ Mass of powder

$\mathrm{v}_{\mathrm{b}}=$ Bulk Volume

\section{Tapped density (TD)}

The pre-weighed powder was filled in measuring cylinder. Then it was tapped in bulk density test apparatus. After 50 taps the volume was measured. It is a measure used to describe void space of powder. The equation for determining tapped density is-

Where,

$$
\rho_{\mathrm{t}}=\mathrm{m} / \mathrm{v}_{\mathrm{t}}
$$

$\rho_{\mathrm{t}}=$ Tapped density 
$\mathrm{m}=$ Mass of powder

$\mathrm{v}_{\mathrm{t}}=$ Tapped volume

Carr's (Compressibility) Index (CI)

Compressibility is indirectly related to the relative flow rate, cohesiveness and particle size distribution of the powder. Tapped density $\left(\rho_{t}\right)$ and bulk density $\left(\rho_{b}\right)$ of powder material was used to measure compressibility of a powder material. The equation for determining Carr's index is:

$$
\text { Carr's index }(\%)=\left(\rho_{\mathrm{t}}-\rho_{\mathrm{b}}\right) / \rho_{\mathrm{t}} * 100
$$

Where,

$\rho_{\mathrm{b}}=$ Bulk density

$\rho_{\mathrm{t}}=$ Tapped density

\section{Hausner's Ratio (HR)}

It is the ratio of bulk volume to tapped volume or tapped density to bulk density. It is a measure used to describe compressibility of powder. Tapped density $\left(\rho_{t}\right)$ and bulk density $\left(\rho_{b}\right)$ of powder material was used to measure Hausner's Ratio.

\section{Angle of Repose}

Angle of repose is the maximum angle possible between pile of powder and horizontal plane. The angle of repose of powder blend was determined by the funnel method. The accurately weight powder blend were taken in the funnel and tip of funnel was blocked by thumb at initially. The height of the funnel was adjusted in such a way the tip of the funnel just touched the apex of the powder blend (fixed at approximately $2 \mathrm{~cm}$ from plane to tip of funnel).

The powder blend was allowed to flow through the funnel freely on to the surface. It is a measure used to describe flow ability of the powder material.

The equation for determining Angle of Repose is

$$
\theta=\tan ^{-1} \mathrm{~h} / \mathrm{r} \text {----------- (5) }
$$

Where,

$\theta=$ Max. angle between pile of powder and horizontal plane

$\mathrm{h}=$ Height of pile of powder

$r=$ Radius of the base of conical pile

\section{Post-compression parameters \\ Hardness}

The prepared tablets were subjected to hardness test. It was carried out by using Monsanto hardness tester and is expressed in $\mathrm{kg} / \mathrm{cm}^{2}$ (Sreenivas and Gadad, 2006).

\section{Friability $(\boldsymbol{F})$}

The friability was determined using Roche friabilator and expressed in percentage (\%). 20 tablets from each batch were weighed separately $\left(\mathrm{W}_{\text {initial }}\right)$ and placed in the friabilator, which was then operated for 100 revolutions at $25 \mathrm{rpm}$. The tablets were reweighed $\left(\mathrm{W}_{\text {final }}\right)$ and the percentage friability was calculated for each batch by using the following formula-

$$
\mathrm{F}=\left(\mathrm{W}_{\text {initial }}-\mathrm{W}_{\text {final }}\right) / \mathrm{W}_{\text {initial }} \mathrm{X} 100
$$

\section{Weight variation test}

The weight variation test is done by taking 20 tablets randomly and weighed accurately. The composite weight divided by 20 provided an average weight of a tablet. The average weight and standard deviation of the tablets were calculated.

\section{Uniformity of drug content}

The drug content in each formulation was determined by triturating 20 tablets and powder equivalent to $10 \mathrm{mg}$ was added in $100 \mathrm{ml}$ of $\mathrm{pH} 6.8$ phosphate buffer followed by stirring for 10 minutes. The solution was filtered through a $0.45 \mu \mathrm{m}$ membrane filter, diluted suitably and the absorbance of resultant solution was measured by using Shimadzu Pharmaspec UV-visible spectrophotometer using pH 6.8 phosphate buffer (Senthilkumar et al., 2012).

\section{Dissolution testing}

In-vitro release of Rabeprazole sodium from compression coated tablets was determined using USP Dissolution Testing Apparatus type II (paddle type). The dissolution test was performed using $900 \mathrm{ml} \mathrm{HCl}$ buffer ( $\mathrm{pH} \mathrm{1.2)} \mathrm{which} \mathrm{was} \mathrm{replaced}$ with phosphate buffer ( $\mathrm{pH}$ 6.8) after two hours. The temperature of the dissolution medium was maintained at $37 \pm 0.5^{\circ} \mathrm{C}$. The speed of rotation of paddle was set at $50 \mathrm{rpm}$.

At a predetermined time interval of 15 minutes, $5 \mathrm{ml}$ samples were withdrawn, filtered through Whatmann filter paper and replaced with equivalent amount of fresh buffer to maintain the in-vitro sink conditions (I.P., 2007; USP 34-NF 29, 2011).

\section{Stability studies of optimized formulation}

Stability of pharmaceutical product may be defined as the capability of a particular formulation, in a specific container/package, to remain within its physical, chemical, therapeutic and toxicological specifications throughout its shelf life (ICH Guidelines, 1996).

\section{Method}

Short-term stability study of final formulation was carried out for 1 month at accelerated stability conditions $\left(40^{\circ} \mathrm{C}\right.$ and $75 \% \mathrm{RH})$. The optimized formulation $\mathrm{C} 5$ was packed in aluminium pouch pack and then exposed to accelerated conditions of temperature and humidity for 1 month. Tablets were evaluated for their physical appearance, drug content and drug-excipient compatibility at specified intervals of time.

\section{RESULTS AND DISCUSSION}

\section{Preformulation Studies}

\section{Organoleptic Properties}

Drug was observed to be a white to slightly yellowishwhite powder with a slightly bitter taste. 


\section{Melting Point}

The value of observed melting point range is given in the table below along with the reported melting point range.

Table 2: Observed Melting Point of Drug.

\begin{tabular}{ccc}
\hline Parameter & Reference value & Experimental value \\
\hline Melting point & $140-141^{\circ} \mathrm{C}$ & $140 \pm 0.6^{\circ} \mathrm{C}$ \\
\hline
\end{tabular}

*Mean \pm S.D.

Assay

The assay showed the drug content as $97 \pm 0.5 \%$ which was found within the official limits (I.P., 2007).

\section{Partition Coefficient}

The aqueous phase and octanol phase were assayed before and after partitioning using UV Spectrophotometer at their respective $\lambda_{\max }$ to get partition coefficient. The $\log \mathrm{p}$ value of RS was found to be 0.549 which is in accordance with the reported value i.e. 0.60 (Mallikarjuna et al., 2010).

\section{pH stability profile}

The stability of Rabeprazole sodium was strongly dependent on the $\mathrm{pH}$ of the solution. The stability of drug was determined in the range of $\mathrm{pH} 1-8$. The results of $\mathrm{pH}$ stability profile are depicted in table 3 . It was found that the stability of the drug increased with increasing $\mathrm{pH}$. The acceptable stability of drug was found at a $\mathrm{pH}$ higher than 5 .

Table 3: $\mathrm{pH}$ stability profile of Rabeprazole sodium

\begin{tabular}{cc}
\hline pH of drug solution & \% of drug after $\mathbf{2 4} \mathbf{~ h r s}$ \\
\hline 1 & 12.23 \\
2 & 29.89 \\
3 & 44.51 \\
4 & 65.22 \\
5 & 78.31 \\
6 & 89.24 \\
7 & 93.88 \\
8 & 95.67 \\
\hline
\end{tabular}

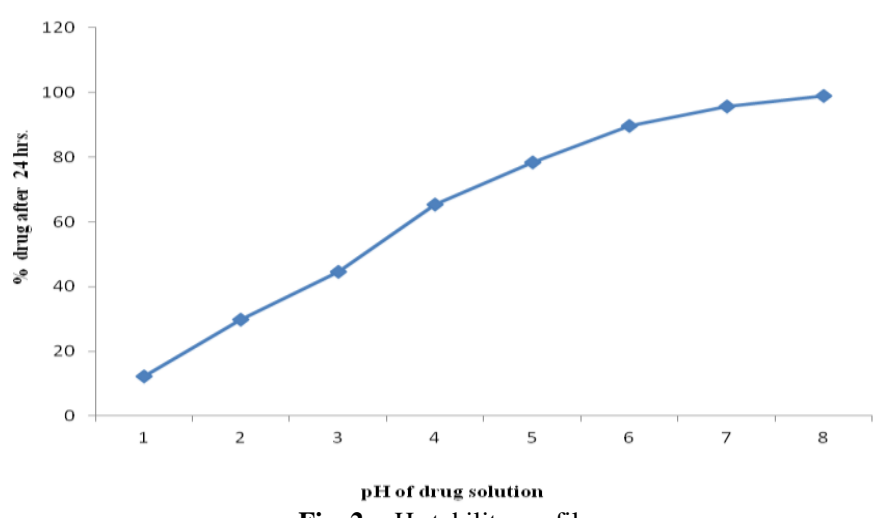

Fig. 2: pH stability profile.

\section{Calibration plot of Rabeprazole sodium in $0.1 \mathrm{~N} \mathrm{HCl}$}

Concentrations of $5-30 \mu \mathrm{g} / \mathrm{ml}$ were analyzed at scanned wavelength of $260 \mathrm{~nm}$ and straight line obtained is shown in the figure below.

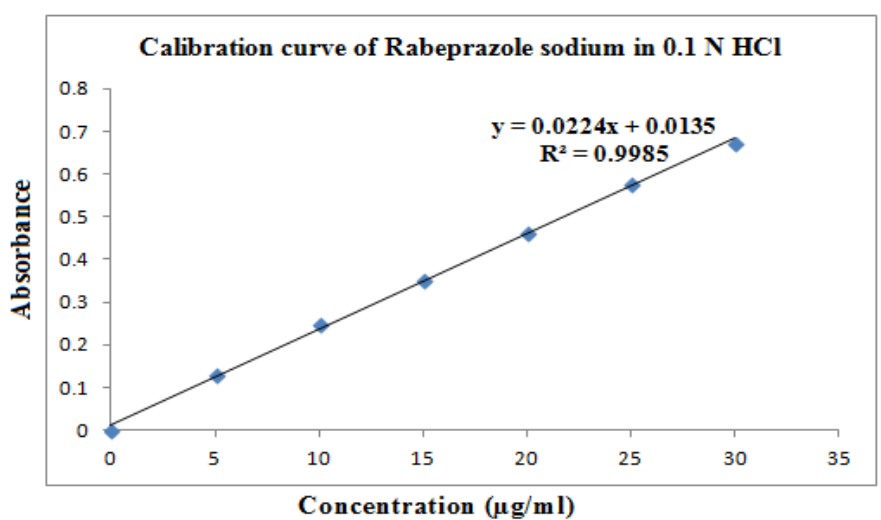

Fig. 3: Calibration plot of $\mathrm{RS}$ in $0.1 \mathrm{~N} \mathrm{HCl}$.

\section{Calibration plot of Rabeprazole sodium in 6.8 phosphate buffer}

The drug in $\mathrm{pH}$ 6.8 Phosphate buffer solution showed a $\lambda_{\max }$ of $284 \mathrm{~nm}$. Different concentrations were analyzed at scanned wavelength (i.e. $284 \mathrm{~nm}$ ) and the straight line equation so obtained is shown in the figure below.

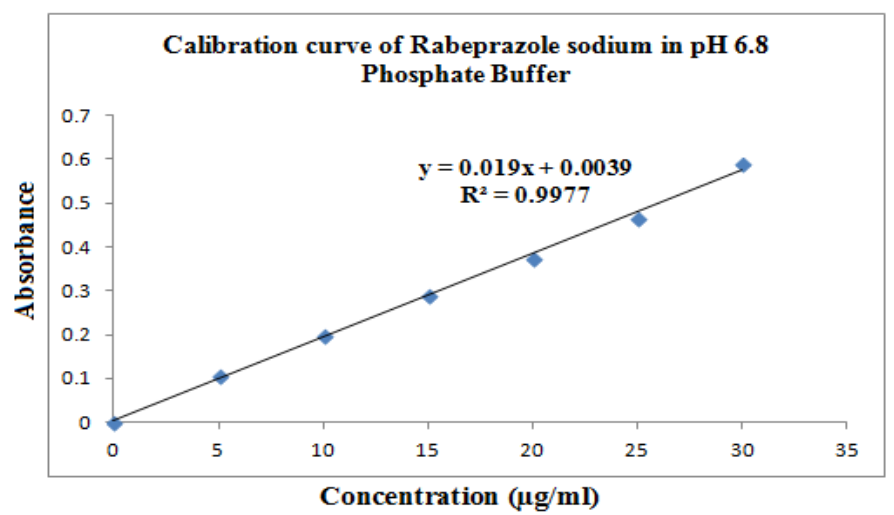

Fig. 4: Calibration plot of RS in pH 6.8 .

\section{FTIR Analysis}

Drug-excipient interactions play a vital role with respect to release of drug from the formulation amongst others. In the FTIR studies, it was observed that there was no chemical interaction between the drug and excipients used as shown in different FTIR spectra and table 4. From the obtained spectra, it was evident that there were no significant changes in the main functional groups of drug in final formulation, which confirmed the absence of any interactions whatsoever.

Table 4: FTIR studies for drug and drug-excipients mixture.

\begin{tabular}{|c|c|c|c|c|c|}
\hline \multirow{2}{*}{$\begin{array}{l}\dot{Z} \\
\dot{\boldsymbol{Z}}\end{array}$} & \multirow{2}{*}{ 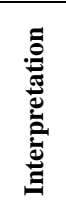 } & \multicolumn{4}{|c|}{ IR absorption bands $\left(\mathrm{cm}^{-1}\right)$} \\
\hline & & $\mathbf{R S}$ & $\begin{array}{c}\text { RS + } \\
\text { HPMCK100M }\end{array}$ & $\mathbf{R S}+\mathbf{E C}$ & Formulation \\
\hline 1 & $\mathrm{~N}-\mathrm{H}$ & 3397.09 & 3397.96 & 3395.19 & 3461.09 \\
\hline 2 & $\mathrm{O}-\mathrm{H}$ & 3361.12 & 3358.17 & 3330.28 & 3297.86 \\
\hline 3 & $\mathrm{CH} 2$ & 3157.39 & 3162.98 & 3176.53 & 3048.08 \\
\hline 4 & $\mathrm{CH} 3$ & 2968.46 & 2973.76 & 2951.36 & 2857.83 \\
\hline 5 & $\mathrm{C}-\mathrm{O}$ & 1590.86 & 1586.59 & 1595.02 & 1587.38 \\
\hline 6 & $\mathrm{~S}=\mathrm{O}$ & 1126.38 & 1113.06 & 1117.90 & 1116.72 \\
\hline
\end{tabular}




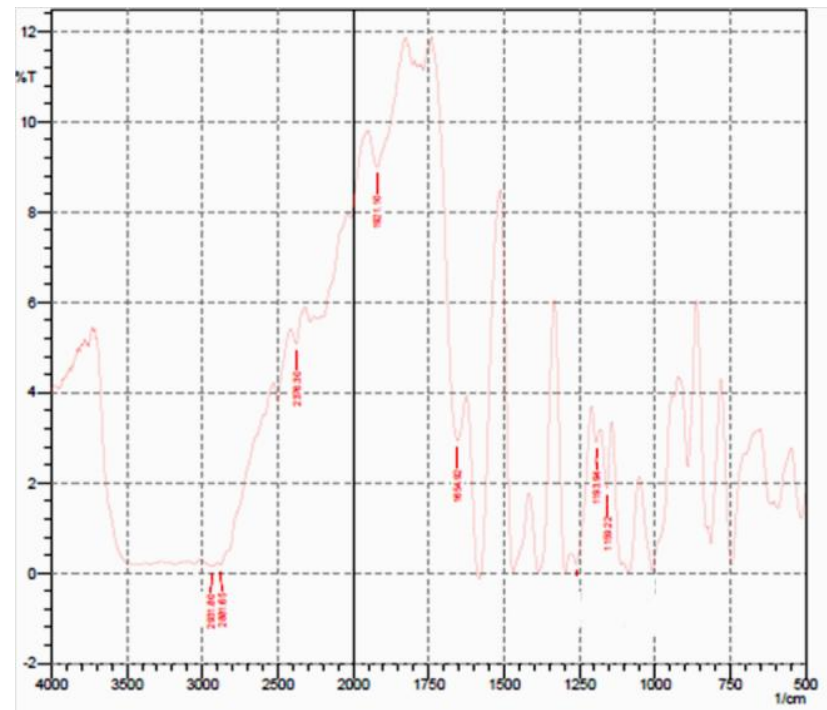

Fig. 5: IR spectrum of Rabeprazole Sodium.

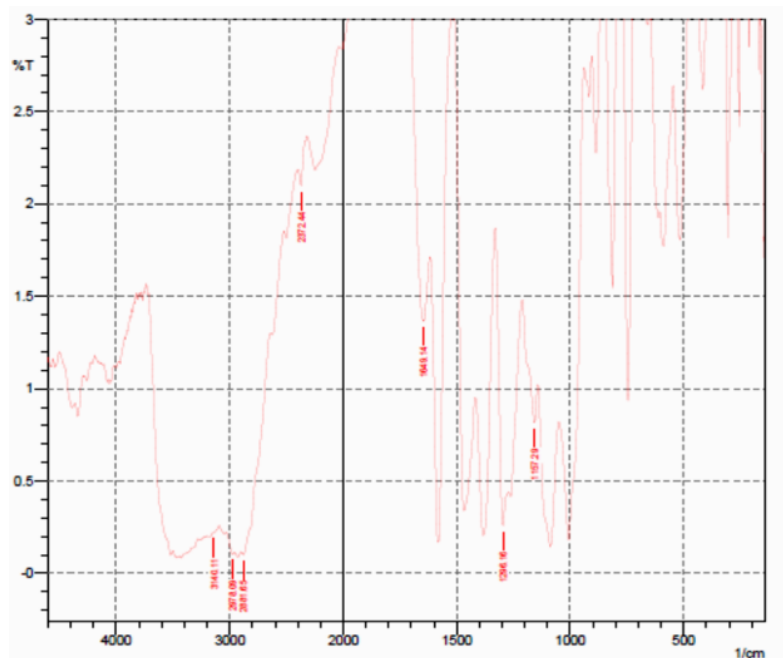

Fig. 6: IR spectra of RS + HPMC K100 M.

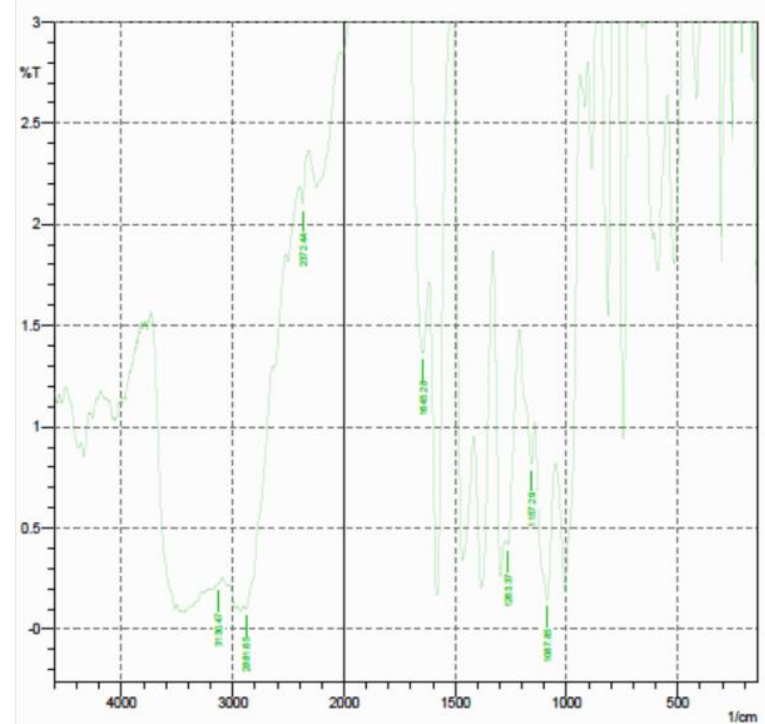

Fig. 7: IR spectra of RS + EC.

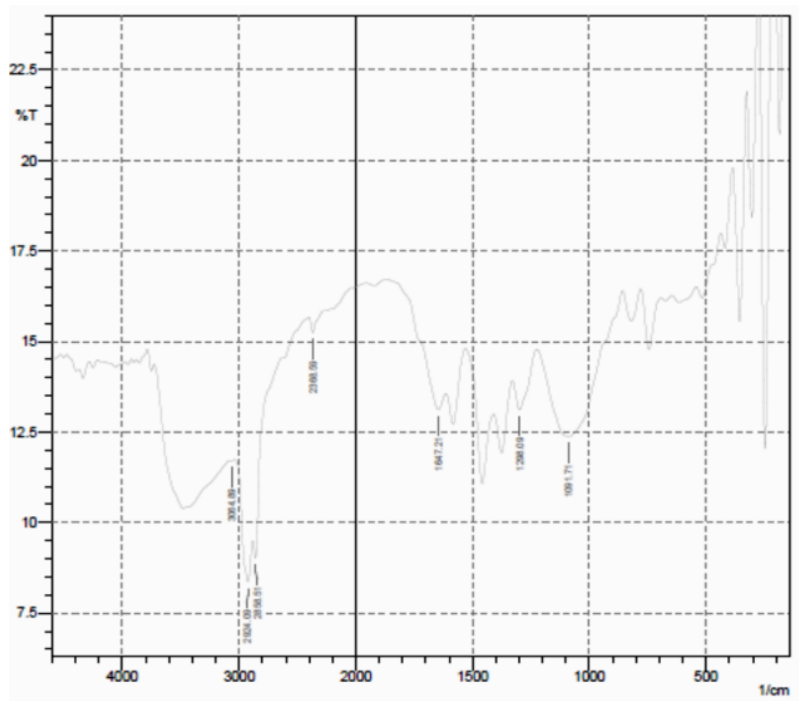

Fig. 8: IR spectra of RS + CCS.

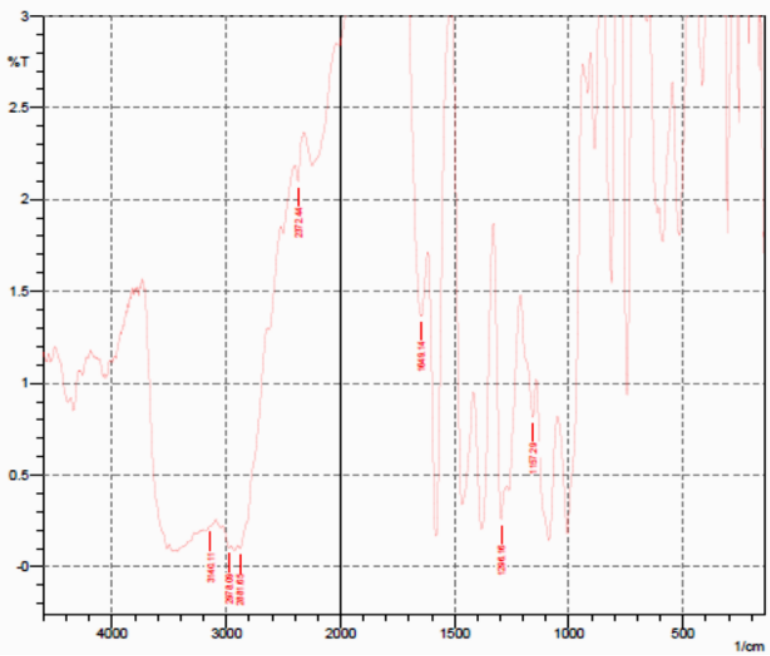

Fig. 9: IR spectra of Drug + all excipients.

\section{Evaluation}

Pre-compression parameters

The results obtained in pre-compression studies are summarized in table below.

Table 5: Pre-compression parameters of formulations.

\begin{tabular}{ccccc}
\hline $\begin{array}{c}\text { Formulation } \\
\text { code }\end{array}$ & $\begin{array}{c}\text { Bulk } \\
\text { density } \\
(\mathbf{g m} / \mathbf{m l}) \\
\mathbf{\pm S D}\end{array}$ & $\begin{array}{c}\text { Tapped } \\
\text { density } \\
(\mathbf{g m} / \mathbf{m l}) \\
\mathbf{\pm S D}\end{array}$ & $\begin{array}{c}\text { Carr' index } \\
(\boldsymbol{\%}) \pm \text { SD }\end{array}$ & $\begin{array}{c}\text { Angle of } \\
\text { Repose }(\boldsymbol{\theta}) \\
\mathbf{\pm S D}\end{array}$ \\
\hline C1 & $0.37 \pm 0.78$ & $0.44 \pm 0.45$ & $21.64 \pm 0.16$ & $21.31 \pm 0.45$ \\
C2 & $0.38 \pm 0.04$ & $0.46 \pm 0.09$ & $14.98 \pm 0.46$ & $34.78 \pm 0.17$ \\
C3 & $0.37 \pm 0.43$ & $0.43 \pm 0.34$ & $17.79 \pm 0.31$ & $31.16 \pm 0.74$ \\
C4 & $0.39 \pm 0.17$ & $0.42 \pm 0.74$ & $16.37 \pm 0.73$ & $22.61 \pm 0.14$ \\
C5 & $0.38 \pm 0.58$ & $0.45 \pm 0.19$ & $11.43 \pm 0.74$ & $26.43 \pm 0.48$ \\
C6 & $0.36 \pm 0.26$ & $0.46 \pm 0.26$ & $19.68 \pm 0.18$ & $31.01 \pm 0.55$ \\
\hline
\end{tabular}

\section{Post compression parameters}

The results obtained for post-compression parameters are summarized in the table 6 . 
Table 6: Post-compression parameters of formulations.

\begin{tabular}{|c|c|c|c|c|c|}
\hline 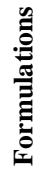 & 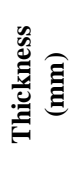 & $\begin{array}{c}\text { Hardness } \\
(\mathrm{Kg} / \mathrm{cm})\end{array}$ & $\begin{array}{c}\text { Friability } \\
(\%)\end{array}$ & $\begin{array}{c}\text { Weight } \\
\text { uniformity } \\
(\mathbf{m g})\end{array}$ & $\begin{array}{c}\text { Percent drug } \\
\text { content }(\%)\end{array}$ \\
\hline $\mathrm{C} 1$ & 3.67 & $6.5 \pm 0.09$ & $0.83 \pm 0.09$ & $210.14 \pm 1.13$ & $98.72 \pm 0.8$ \\
\hline $\mathrm{C} 2$ & 3.87 & $6.8 \pm 0.21$ & $0.39 \pm 0.02$ & $194.54 \pm 1.31$ & $98.61 \pm 0.12$ \\
\hline C3 & 3.50 & $5.7 \pm 0.47$ & $0.77 \pm 0.07$ & $192.09 \pm 0.97$ & $99.21 \pm 0.5$ \\
\hline $\mathrm{C} 4$ & 4.04 & $6.6 \pm 0.06$ & $0.91 \pm 0.12$ & $197.17 \pm 2.28$ & $97.92 \pm 0.9$ \\
\hline C5 & 3.51 & $6.1 \pm 0.87$ & $0.59 \pm 0.08$ & $200.64 \pm 1.12$ & $99.96 \pm 0.7$ \\
\hline C6 & 3.29 & $5.5 \pm 0.52$ & $0.78 \pm 0.13$ & $207.66 \pm 0.91$ & $99.43 \pm 0.6$ \\
\hline
\end{tabular}

\section{Optimized formulation}

From all the prepared formulations, the best formulation (C5) was selected based on physiochemical and compression parameters.

\section{Stability study}

The optimized formulation (i.e. C5) was packed in aluminum pouch and charged for accelerated stability studies at $40^{\circ} \mathrm{C}$ and $75 \% \mathrm{RH}$, for 1 month. The tablets were evaluated for their physical appearance and post-compression parameters at specified intervals of time. Formulation C5 was found to be stable during the stability study of 1 month without any significant changes in post compression parameters as shown in table 7 .

Table 7: Stability study parameters obtained before and after a period of 1 month

\begin{tabular}{ccccc}
\hline $\begin{array}{c}\text { Sr. } \\
\text { No. }\end{array}$ & Parameters & Initial & $\begin{array}{c}\text { After 15 } \\
\text { davs }\end{array}$ & $\begin{array}{c}\text { After 1 } \\
\text { month }\end{array}$ \\
\hline 1 & $\begin{array}{c}\text { Physical } \\
\text { appearance } \\
\text { Weight variation } \\
(\mathrm{mg})\end{array}$ & $\begin{array}{c}\text { White to off } \\
\text { white }\end{array}$ & No change & No change \\
2 & $200.64 \pm 1.12$ & $200 \pm 1.17$ & $200 \pm 1.53$ \\
3 & Friability $(\%)$ & $0.59 \pm 0.08$ & $0.59 \pm 0.03$ & $0.58 \pm 0.07$ \\
4 & Thickness (mm) & $3.51 \pm 0.75$ & $3.51 \pm 1.54$ & $3.51 \pm 1.11$ \\
5 & Hardness & $6.1 \pm 0.87$ & $6.1 \pm 0.34$ & $6.1 \pm 0.94$ \\
\hline
\end{tabular}

\section{In-vitro drug release studies}

In-vitro drug release of RS from compression coated tablets was determined using USP dissolution testing apparatus II
(Paddle type). The dissolution test was performed using $900 \mathrm{ml}$ $\mathrm{HCl}$ buffer ( $\mathrm{pH}$ 1.2) which was replaced with phosphate buffer (pH 6.8) after two hours. Temperature was maintained at $37 \pm$ $0.50^{\circ} \mathrm{C}$.

The speed of rotation of paddle was set at $50 \mathrm{rpm}$. At a predetermined time interval of 15 minutes, $5 \mathrm{ml}$ samples were withdrawn, filtered through Whatman filter paper. The system released the drug rapidly after a certain lag time due to the rupture of the HPMC K100M and ethyl cellulose film as shown in table 8 . Absorbance of solution was checked by UV spectrophotometer and drug release was determined from standard curve. The optimized formulation C5 was found to give maximum cumulative drug release of $99.97 \%$ in 195 minutes. The drug release profiles from various formulations are shown in figure 10 .

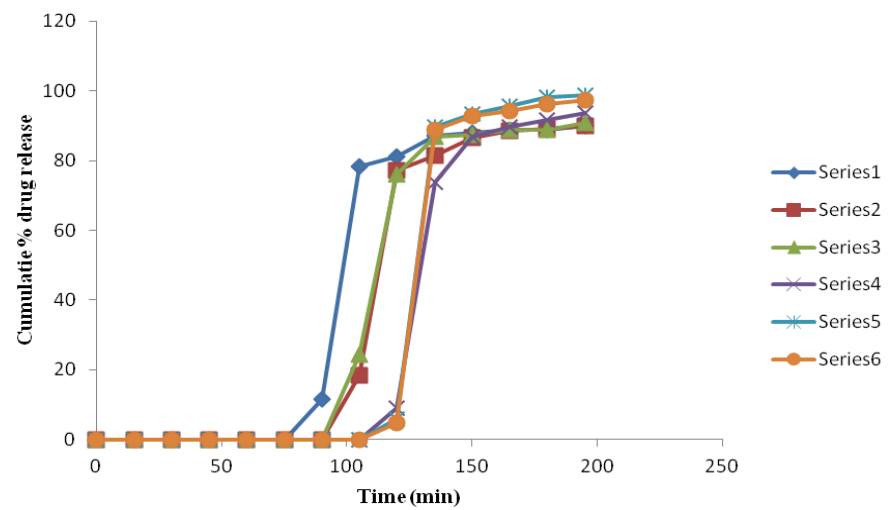

Fig. 10: In-vitro drug release profile of RS from C1-6 formulations.

HPMC K100M was chosen because of its swelling nature and its eroding behavior and was applied by direct compression method. The rupturable coating consisted of a plasticized mixture of EC as it forms a mechanically weak and semipermeable film, which could rupture easily upon exposure to the dissolution media and was water insoluble. Water influx was through the semipermeable rupturable outer coating which led to rupture of the outer coating and drug was released within a short time after a definite lag time period (Akila and Sharma, 2013).

Table 8: In-vitro drug release study.

\begin{tabular}{|c|c|c|c|c|c|c|}
\hline \multirow[t]{2}{*}{ Time (min) } & \multicolumn{6}{|c|}{ \% Cumulative Drug release from formulations } \\
\hline & C1 & $\mathbf{C 2}$ & $\mathrm{C3}$ & $\mathrm{C4}$ & C5 & C6 \\
\hline 0 & 0 & 0 & 0 & 0 & 0 & 0 \\
\hline 15 & 0 & 0 & 0 & 0 & 0 & 0 \\
\hline 30 & 0 & 0 & 0 & 0 & 0 & 0 \\
\hline 45 & 0 & 0 & 0 & 0 & 0 & 0 \\
\hline 60 & 0 & 0 & 0 & 0 & 0 & 0 \\
\hline 75 & 0 & 0 & 0 & 0 & 0 & 0 \\
\hline 90 & $11.5 \pm 0.15$ & 0 & 0 & 0 & 0 & 0 \\
\hline 105 & $78.21 \pm 0.23$ & $18.27 \pm 0.28$ & $24.31 \pm 0.23$ & 0 & 0 & 0 \\
\hline 120 & $81.09 \pm 0.38$ & $77.19 \pm 0.34$ & $75.89 \pm 0.35$ & $9.13 \pm 0.27$ & $5.95 \pm 0.69$ & $4.76 \pm 0.34$ \\
\hline 135 & $83.12 \pm 0.36$ & $81.56 \pm 0.39$ & $84.93 \pm 0.42$ & $73.67 \pm 0.43$ & $89.62 \pm 0.19$ & $88.78 \pm 0.38$ \\
\hline 150 & $87.89 \pm 0.17$ & $86.45 \pm 0.17$ & $87.45 \pm 0.49$ & $86.91 \pm 0.46$ & $93.46 \pm 0.36$ & $90.71 \pm 0.23$ \\
\hline 165 & $88.67 \pm 0.31$ & $88.63 \pm 0.46$ & $88.85 \pm 0.25$ & $89.65 \pm 0.31$ & $95.54 \pm 0.39$ & $94.17 \pm 0.31$ \\
\hline 180 & $88.91 \pm 0.62$ & $89.13 \pm 0.35$ & $88.94 \pm 0.51$ & $91.78 \pm 0.19$ & $98.04 \pm 0.17$ & $96.08 \pm 0.18$ \\
\hline 195 & $89.83 \pm 0.46$ & $89.97 \pm 0.41$ & $90.78 \pm 0.16$ & $93.70 \pm 0.34$ & $99.97 \pm 0.51$ & $97.46 \pm 0.43$ \\
\hline
\end{tabular}




\section{CONCLUSION}

In the present study, pulsatile drug delivery system of Rabeprazole sodium for effective treatment of Peptic Ulcer was formulated. Each tablet contained $20 \mathrm{mg}$ of drug. The study includes preformulation of drug and excipients, formulation, evaluation and stability studies of pulsatile release tablets. The pulsatile tablets prepared by compression coating method consisted of two different parts: a core tablet, containing the active ingredient along with superdisintegrant, and an erodible outer coating layer composed of HPMC K100M and ethyl cellulose along with xanthum gum as binder. The effect of formulation composition on the barrier layer comprising both polymers, excipients on the lag time of drug release was investigated. The compression coated tablets were further evaluated for weight variation test, thickness, hardness, friability, lag time and dissolution study. Stability studies were conducted for the optimized formulation at $40^{\circ} \mathrm{C} / 75 \% \mathrm{RH}$ (accelerated stability testing) for 1 month. During study, 6 formulations of RS were developed amongst which formulation C5 was observed to possess the best result in terms of compression parameters as well as cumulative percentage drug release. The system released the drug rapidly after a certain lag time due to the rupture of the HPMC K100M and EC film. Since the formulation was developed to be taken at bedtime, the tablet would be expected to release the drug contained in its core after a desired lag time and the activity of the enzyme would be restricted to minimum providing better control of peptic ulcer. The lag time of the system could be modified by level of swelling layer and rupturable coating. Thus the novel time controlled chronotherapeutic pulsatile drug delivery system for oral use was successfully developed and evaluated; the concept, however, needs to be further confirmed with in-vivo studies.

\section{Financial support and sponsorship: Nil.}

Conflict of Interests: There are no conflicts of interest.

\section{REFERENCES}

Akila RM, Sharma B. Chronotherapeutic formulation of metformin hydrochloride. Der Pharmacia Sinica, 2013; 4:67-71.

Arora S, Ali J, Ahuja A, Baboota S, Qureshi J. Pulsatile Drug Delivery Systems: An Approach for Controlled Drug Delivery. Ind J Pharm Sci, 2006; 68:295-300.

Carter SJ. 1986. Cooper and Gunn's Tutorial Pharmacy, $6^{\text {th }}$ ed. New Delhi, India: CBS Publisher and Distributor.

Duppada DR, Swapna R, Gourisankar K, Rao KR, Sarbudeen S. Formulation \& In vitro Evaluation of Novel Floating Pulsatile Approach for the Chronotherapeutic Release of Nizatidine-A Time \& Site Specific Drug Delivery System. Int J Biol Pharm Res, 2014; 5:436-442.

Fabio P, Stefano P, Stefania C, Gabriele BP. A review of rabeprazole in the treatment of acid-related diseases. Therap Clin Risk Management, 2007; 3:363-379.

Gandhi M, Chaudhari R, Kulkarni N, Bhusare S, Kare P. Review Article on Pulsatile drug delivery system. Int J Pharm Sci Rev Res, 2014; 26:251-255.

Hatlebakk JG, Berstad, A. Endoscopic grading reflux esophagitis: whar observations correlate with gastroesophageal reflux? Scand J Gastroenterol, 1997; 32:760-765.
ICH, Accelerated stability testing of new drug substances and products, Geneva. International conference on Harmonization. Nov 1996.

Indian Pharmacopoeia. Published by Indian Pharmacopoeia Commission, Ministry of Health and Family Welfare, Government of India, Ghaziabad, 2007.

Jona JA, Dittert LW, Crooks PA, Hussain AA. Design of novel prodrugs for the enhancement of the transdermal penetration of indomethacin. Int J Pharm, 1995; 123:127-136.

Kadam VD and Gattani SG. Formulation and evaluation of a pulsatile drug delivery system using time- and $\mathrm{pH}$-dependant polymers. Pharm Dev Technol, 2010; 15:57-63.

Kadam VS, Chavare SS, Patil SS, Kale SS, Muttepawar SS, Bharkad VB et al. Pulsatile drug delivery system. World J Pharmacy Pharm Sci, 2016; 5:609-624.

Mallikarjuna GM, Somashekar S, Putta RK, Kumar SMS. Physico-chemical characterization, UV spectrophotometric analytical method development and validation studies of Rabeprazole Sodium. J Chem Pharm Res, 2010; 2:187-192.

Maroni A, Zema L, Del Curto MD, Loreti G, Gazzaniga A. Oral pulsatile delivery: rationale and chronopharmaceutical formulations. Int $\mathbf{J}$ Pharm, 2010; 398:1-8.

Parmar RD, Parikh RK, Vidyasagar G, Patel DV, Patel CJ, Patel BD. Pulsatile Drug Delivery Systems: An Overview. Int J Pharm Sci Nanotechnol, 2009; 2:605-614.

Ramakrishna M and Rani AP. Review on recent trends and approach for pulsatile drug delivery systems. Europ J Pharm Med Res, 2016; 3:268-275.

Senthikumar KL, Muthukumaran M, Chenchuratnam B. Formulation and evaluation of rabeprazole sodium enteric coated pellets. Int J Adv Pharm Biol Chem, 2012; 1:7-14.

Shaker R, Castell DO, Schoenfeld P, Spechler Sj. Night-time heartburn is an under-appreciated clinical problem that impacts sleep and day-time function: the results of a Gallup survey conducted on behalf of the American Gastroenterological Association. Am J Gastroenterol, 2003; 98:1487-1493.

Singh NP, Ganarajan G, Kothiyal P. Pulsatile drug delivery system: a review. World J Pharmacy Pharm Sci, 2016; 5:479-491.

Singh S and Koland M. Formulation and evaluation of pulsatile drug delivery systems of glipizide for the management of type-II diabetes mellitus. J Drug Del Therap, 2016; 6:11-18

Sinko PJ, Singh Y. 2011. Martin's Physical Pharmacy and Pharmaceutical Sciences. $6^{\text {th }}$ ed. New York: Lipponcott Williams and Wilkins.

Solanki AJ, Jaiswal JJ, Yadav SK. A recent approach on pulsatile drug delivery system. J Pharm Sci Biosci Res, 2016; 6:231-238.

Sreenivas SA and Gadad AP. Formulation and evaluation of Ondansetron $\mathrm{HCl}$ directly compressed mouth disintegrating tablets. Indian Drugs, 2006; 43:35-38.

Tirpude RN, Puranik PK. Rabeprazole sodium delayed-release multiparticulates: Effect of enteric coating layers on product performance. J Adv Pharm Tech Res, 2011; 2:184-191.

United States Pharmacopeia and National Formulary (USP 34NF 29). Rockville, M.D: United States Pharmacopeia Convention; 2011.

Van Herwaarden MA, Samsom M, Smout AJ. 24-h recording of intragastric $\mathrm{pH}$ : technical aspects and clinical relevance. Scand J Gastroenterol Suppl, 1999; 230:9-16.

\section{How to cite this article:}

Garg AK, Kumar A, Rani S, Singh M, Sharma A, Kumar R. Formulation and Evaluation of Chronotherapeutic Pulsatile Drug Delivery System Containing Rabeprazole Sodium. J App Pharm Sci, 2017; 7 (02): 093-100. 